\title{
Non contiguous-finished genome sequence of Pseudomonas syringae pathovar syringae strain B64 isolated from wheat
}

\author{
Alexey Dudnik and Robert Dudler \\ Institute of Plant Biology, University of Zurich, Zurich, Switzerland \\ Corresponding author: Robert Dudler (rdudler@botinst.uzh.ch) \\ Keywords: Pseudomonas syringae, genome, syringolin, wheat, plant-pathogen interactions \\ The Gram-negative gammaproteobacterium Pseudomonas syringae is one of the most wide- \\ spread plant pathogens and has been repeatedly reported to cause significant damage to crop \\ plantations. Research on this pathogen is very intensive, but most of it is done on isolates that \\ are pathogenic to Arabidopsis, tomato, and bean. Here, we announce a high-quality draft ge- \\ nome sequence of Pseudomonas syringae pv. syringae B64 which is the first published ge- \\ nome of a $P$. syringae strain isolated from wheat up to date. The genome sequence will assist \\ in gaining insights into basic virulence mechanisms of this pathogen which has a relatively \\ small complement of type III effectors.
}

\begin{abstract}
Abbreviations: Pss- Pseudomonas syringae pathovar syringae, Pto- Pseudomonas syringae pathovar tomato, Pph- Pseudomonas syringae pathovar phaseolicola, EPS- Exopolymeric substances, NRPS- non-ribosomal peptide synthetase, MLST- multilocus sequence typing
\end{abstract}

\section{Introduction}

Pseudomonas syringae strains have been isolated from more than 180 host species [1] across the entire plant kingdom, including many agriculturally important crops, such as bean, tomato, cucumber, as well as kiwi, stone fruit, and olive trees. Strains are divided into more than 50 pathovars primarily based on host-specificity, disease symptoms, and biochemical profiles [2-4]. The first strain of this species was isolated from a lilac tree (Syringa vulgaris), which gave origin to its name [5].The observed wide host range is reflected in a relatively large genetic heterogeneity among different pathovars. This is most pronounced in the complement of virulence factors, which is also assumed to be the key factor defining host specificity [6]. For successful survival and reproduction, both epiphytic and endophytic $P$. syringae strains deploy different sets of type III and type VI secretion system effectors, phytotoxins, EPS, and other types of secreted molecules [6-11]. Currently, there are three completely sequenced $P$. syringae genomes published: pathovar syringae strain B728a which causes brown spot disease of bean [12], pathovar tomato strain DC3000 which is pathogenic to tomato and Arabidopsis [13], and pathovar phaseolicola strain 1448A, causal agent of halo blight on bean [14]. There are also a number of incomplete genomes of various qualities available for other strains.

Pseudomonas syringae pv. syringae strain B64 was isolated from hexaploid wheat (Triticum aestivum) in Minnesota, USA [15]. The strain has been deployed in several studies mainly addressing phylogenetic diversity of $P$. syringae varieties [15-18], but never as an infection model for wheat. The genome sequencing of the B64 strain and its comparison with the other published genomes should reveal wheat-specific adaptations and give insights in virulence strategies for colonizing monocot plants.

\section{Classification and features}

Pseudomonas syringae belongs to class Gammaproteobacteria. Detailed classification of this species is still under heavy debate. Young and colleagues have proposed to group all plantpathogenic oxidase-negative and fluorescent Pseudomonas strains into a single species, $P$. syringae, which is to be further sub-divided into 
pathovars [4,19]. Several DNA hybridization studies have shown a large genetic heterogeneity among the groups, however biochemical characteristics, with a few exceptions, did not allow elevating those into distinct species [20,21]. Currently, the species is divided into five phylogenetic clades based on MLST analysis. P. syringae pv. syringae (Pss) strains belong to group II within this nomenclature [22]. The basic characteristics of Pss B64 are summarized in Table 1, while its phylogenetic position is depicted in Figure 1.

Table 1. Classification and the general features of $P$. syringae pv. syringae B64 according to the MIGS recommendations [23]

\begin{tabular}{|c|c|c|c|}
\hline MIGS ID & Property & Term & Evidence code $^{\mathrm{a}}$ \\
\hline & \multirow{9}{*}{ Current classification } & Domain Bacteria & TAS [24] \\
\hline & & Phylum Proteobacteria & TAS [25] \\
\hline & & Class Gammaproteobacteria & TAS $[26,27]$ \\
\hline & & Order Pseudomonadales & TAS $[28,29]$ \\
\hline & & Family Pseudomonadaceae & TAS $[30,31]$ \\
\hline & & Genus Pseudomonas & TAS [30-34] \\
\hline & & Species Pseudomonas syringae & TAS $[30,35]$ \\
\hline & & Pathovar syringae & TAS [36] \\
\hline & & Strain B64 & TAS $[15,16]$ \\
\hline & Gram stain & Negative & TAS [37] \\
\hline & Cell shape & Rod-shaped & TAS [37] \\
\hline & Motility & Motile & TAS [37] \\
\hline & Sporulation & None & TAS [37] \\
\hline & Temperature range & Mesophilic & TAS [38] \\
\hline & Optimum temperature & $28^{\circ} \mathrm{C}$ & TAS [38] \\
\hline \multirow[t]{3}{*}{ MIGS-22 } & Oxygen & Aerobic & TAS [37] \\
\hline & Carbon source & Heterotrophic & TAS [36] \\
\hline & Energy metabolism & Chemoorganotrophic & TAS [37] \\
\hline MIGS-6 & Habitat & Host-associated & TAS $[17,36,37]$ \\
\hline MIGS-6.3 & Salinity & Not reported & \\
\hline MIGS-10 & Extrachromosomal elements & None & IDA \\
\hline MIGS-11 & Estimated Size & $5.93 \mathrm{Mb}$ & IDA \\
\hline MIGS-15 & Biotic relationship & Parasitic & NAS \\
\hline \multirow[t]{6}{*}{ MIGS-14 } & Pathogenicity & Pathogenic & TAS [19] \\
\hline & Host & Triticum aestivum & TAS $[15,17]$ \\
\hline & Host taxa ID & 4565 & \\
\hline & Cell arrangement & Single & TAS \\
\hline & Biosafety level & 1 & NAS \\
\hline & Isolation source & Leaf & NAS \\
\hline MIGS-4 & Geographic location & Minnesota, USA & TAS [15] \\
\hline MIGS-5 & Sample collection time & Not reported & \\
\hline MIGS-4.1 & Latitude & Not reported & \\
\hline MIGS-4.2 & Longitude & Not reported & \\
\hline MIGS-4.3 & Depth & Not reported & \\
\hline MIGS-4.4 & Altitude & Not reported & \\
\hline
\end{tabular}

aEvidence codes - IDA: Inferred from Direct Assay (first time in publication); TAS: Traceable Author Statement (a direct report exists in the literature); NAS: Non-traceable Author Statement (not directly observed for the living, isolated sample, but based on a generally accepted property of the species, or anecdotal evidence). These evidence codes are from the Gene Ontology project [39]. 


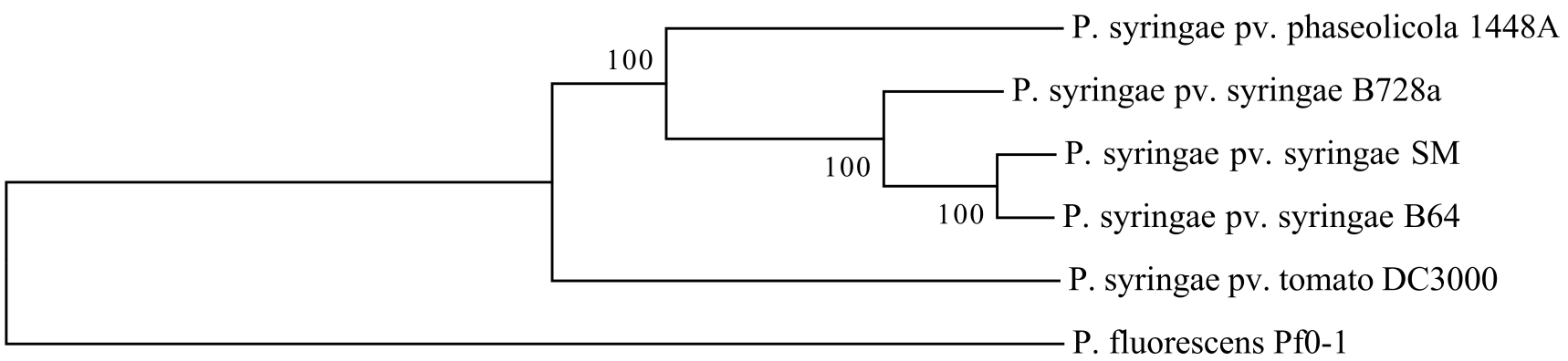

0.02

Figure 1. Phylogenetic tree constructed using neighbor-joining method using MLST approach [40] and MEGA 5.10 software suit [41] with 1,000 bootstraps. The tree features the three completely sequenced $P$. syringae model strains $P$ to DC3000, PSS B728a, and Pph 1448A, the strain PSS B64 itself, as well as another wheat-isolated strain PSS SM. The model strains represent the major phylogenetic clades of $P$. syringae: I, II and III respectively. P. fluorescens Pf0-1 was used as an outgroup. The analysis confirms placement of PSS B64 into clade II.

Pss B64 has similar physiological properties as other representatives of its genus. It can grow in complex media such as LB [42] or King's B [43], as well as in various defined minimal media: HSC [44], MG-agar [45], PMS [46], AB-agar [47], and $\mathrm{SRM}_{\mathrm{AF}}$ [48]. Even though the optimal growth temperature is $28^{\circ} \mathrm{C}$, the bacterium can also replicate at $4^{\circ} \mathrm{C}$. Growth is completely inhibited above $35^{\circ} \mathrm{C}$. Pss B64 is capable of endophytic growth in the wheat leaf mesophyll, but does not seem to cause any symptoms unless a very high inoculation dose is applied.

The bacterium has a weak resistance to ampicillin $(25 \mathrm{mg} / \mathrm{L})$ and chloramphenicol $(10 \mathrm{mg} / \mathrm{L})$. It is also possible to develop spontaneous rifampicinresistant mutants. In addition, the genomic sequence predicts this strain to be polymyxin B insensitive due to presence of the arn gene cluster.

\section{Genome sequencing information Genome project history}

The organism was selected for sequencing because it has been identified to have a syringolin biosynthesis gene cluster [49]. Syringolin is a proteasome inhibitor produced by some strains of pathovar syringae. As a consequence of proteasome inactivation a number of plant intracellular pathways are being inhibited, including the entire salicylic acid-dependent defense pathway, thus promoting the entry of bacteria into leaf tissue and subsequent endophytic growth [9]. Since up to now it has not been possible to establish an infection model for syringolin in the model plant Arabidopsis, it was decided to explore another common research target and one of the most important crop plants, bread wheat (Triticum aestivum). The genome project has been deposited in the Genbank Database (ID 180994) and the genome sequence is available under accession number ANZF00000000. The version described in this paper is the first version, ANZF01000000. The details of the project are shown in Table 2.

\section{Growth conditions and DNA isolation}

$P$. syringae pv. syringae strain $\mathrm{B} 64$ was grown in $40 \mathrm{~mL}$ of $\mathrm{LB}$ medium at $28^{\circ} \mathrm{C}, 220 \mathrm{rpm}$ until $\mathrm{OD}_{600}$ of $\sim 1.0$. Genomic DNA was isolated from the pelleted cell using a Qiagen Genomic-tip 100/G column (Qiagen, Hilden, Germany) according to the manufacturer's instructions.

\section{Genome sequencing and assembly}

A $3 \mathrm{~kb}$ paired-end library was generated and sequenced at the Functional Genomics Center Zurich on a Roche Genome Sequencer FLX+ platform. A total of 872,570 high-quality filtered reads with a total of $188,465,376$ bases were obtained, resulting in 31.8-fold average sequencing coverage. The obtained reads were assembled de novo using Newbler 2.5.3. This resulted in 150 contigs combined into one $6 \mathrm{Mb}$-long super-scaffold and 3 smaller scaffolds of $5.29 \mathrm{~kb}, 2.84 \mathrm{~kb}$ and $2.74 \mathrm{~kb}$ in size. The largest of the minor scaffolds constituted a ribosomal RNA operon, the other two showed sequence similarity to non-ribosomal peptide 
synthase modules. A portion of intra-scaffold gaps have been closed by sequencing of PCR products using Sanger technology, decreasing the total number of contigs to 41 with a contig N50 value of $329.4 \mathrm{~kb}$, the longest contig being $766.5 \mathrm{~kb}$ long. Note that the Genbank record contains 42 contigs due to fact that one of the contigs was split into two parts in order to start the assembly with the dnaA gene. While closing gaps it became possible to allocate the positions of all ribosomal operons by sequence overlap and thus to incorporate the largest of the minor scaffolds. However, it was not possible to precisely map the remaining two minor scaffolds. These must be located within two distinct remaining large gaps, but due to insignificance to the project they have been excluded from the assembly.

Table 2. Genome sequencing project information

\begin{tabular}{lll}
\hline MIGS ID & Property & Term \\
\hline MIGS-31 & Finishing quality & High-quality draft \\
MIGS-28 & Libraries used & 3kb paired-end library \\
MIGS-29 & Sequencing platform & Roche Genome Sequencer FLX+ \\
MIGS-31.2 & Sequencing coverage & $31.8 \times$ \\
MIGS-30 & Assembler & Newbler 2.5.3 \\
MIGS-31.3 & Contigs & 41 \\
MIGS-32 & Gene calling method & RAST server \\
& NCBI project ID & 180994 \\
& NCBI accession number & ANZF00000000 \\
& Date of release & January 18,2013 \\
& GOLD ID & Gc02493 \\
& Database: IMG/ER & 2523533564 \\
& Project relevance & Plant-pathogen interactions, model for syringolin effects \\
\hline
\end{tabular}

\section{Genome annotation}

Initial open-reading frame (ORF), tRNA, and rRNA prediction and functional annotation has been performed using the RAST (Rapid Annotation using Subsystem Technology) server [50]. For the purpose of comparison, the genome has also been annotated using Prokka [51], which utilizes Prodigal [52] for ORF prediction (the RAST server utilizes a modified version of Glimmer [53]). Start codons of all the predicted ORFs were further verified manually, using the position of potential ribosomal binding sites and BLASTP [54] alignments with homologous ORFs from other $P$. syringae strains as a reference. Functional annotations have also been refined for every ORF using BLASTP searches against the non-redundant protein sequence database (nr) and the NCBI Conserved-Domain search engine [55]. Functional category assignment and signal peptide prediction was done using the Integrated Microbial Genomes/Expert reviews (IMG/ER) system [56].

\section{Genome properties}

The genome of the strain B64 is estimated to be comprised of 5,930,035 base pairs with an average GC-content of $58.55 \%$ (Table 3 and Figure 2), which is similar to what is observed in other $P$. syringae strains $[12,13,53]$. Of the 5,021 predicted genes, 4,947 were protein coding genes, 4 ribosomal RNA operons, and 61 tRNA genes; 78 were identified to be pseudo-genes. The majority of the protein-coding genes (83.65\%) were assigned a putative function, while the remaining ones were annotated as hypothetical proteins. The distribution of genes into COGs functional categories is presented in Table 4.

The genome contains a complete canonical type III secretion system and ten known effector proteins: AvrE1, HopAA1, HopI1, HopM1, HopAH1, HopAG1, HopAI1, HopAZ1, HopBA1, and HopZ3. Out of these ten, the first five are present in all other sequenced $P$. syringae strains, thereby constituting the effector core, whereas the latter five could be 
host-determinants for wheat. That there is such a small number of effectors is not something unusu$\mathrm{al}$, and is seen in other strains of clade II [22]. In addition, there are two complete type VI secretion system gene clusters and nine putative effector proteins belonging to the VgrG and Hcp1 families. Pss B64 genome also encodes gene clusters for biosynthesis of four phytotoxin: syringomycin, syringopeptin, syringolin, and mangotoxin. All of the above-mentioned genome components have been previously demonstrated to be involved in virulence, epiphytic fitness of $P$. syringae, as well as in competition with other microbial species [710,57-59]. Additional identified virulenceassociated traits are: exopolysaccharides alginate, Psl, and levan biosynthesis, surfactant syringofactin, type VI pili, large surface adhesins, siderophores pyoverdine and achromobactin, proteases and other secreted hydrolytic enzymes, RND-type transporters (including putative mex $A B$, mexCD, mexEF, and mexMN homologs [60,61]), all of which are found in other $P$. syringae strains. It is also notable that inaZ gene encoding icenucleation protein is truncated by a frameshift, thus making this strain ice-negative. The latter contradicts results of a previous study by Hwang and colleagues [16] in which Pss B64 has been identified to be ice-positive. This could be due to an assembly error, or the frameshift could have been introduced at a later point during propagation.

Table 3. Genome Statistics

\begin{tabular}{|c|c|c|}
\hline Attribute & Value & $\%$ of Total \\
\hline Estimated genome size (bp) & $5,930,035$ & 100.00 \\
\hline Estimated total gap length (bp) & 56,737 & 0.96 \\
\hline DNA coding region (bp) & $5,146,184$ & 86.78 \\
\hline DNA G+C content $(b p)$ & $3,472,195$ & 58.55 \\
\hline Number of replicons & 1 & - \\
\hline Extra-chromosomal elements & 0 & - \\
\hline Total genes & 5,021 & 100.00 \\
\hline Protein-coding genes ${ }^{\mathrm{a}}$ & 4,869 & 96.97 \\
\hline RNA genes & 74 & 1.47 \\
\hline rRNA genes & 13 & 0.26 \\
\hline $5 \mathrm{~S}$ rRNA & 5 & 0.10 \\
\hline $16 \mathrm{~S}$ rRNA & 4 & 0.08 \\
\hline $23 \mathrm{~S}$ rRNA & 4 & 0.08 \\
\hline tRNA genes & 61 & 1.21 \\
\hline rRNA operons & 4 & - \\
\hline Pseudo-genes & 78 & 1.55 \\
\hline Protein coding genes with function prediction & 4,200 & 83.65 \\
\hline without function prediction ${ }^{a}$ & 669 & 13.32 \\
\hline Protein coding genes with COGs & 4,013 & 79.92 \\
\hline with KOGs & 1,698 & 33.82 \\
\hline with Pfam & 4,256 & 84.76 \\
\hline with TIGRfam & 1,641 & 32.68 \\
\hline in paralog clusters & 3,933 & 78.33 \\
\hline Proteins with signal peptides & 511 & 10.18 \\
\hline Proteins with transmembrane helices & 1,112 & 22.15 \\
\hline
\end{tabular}

aexcluding pseudo-genes; therefore percentage values differ from those displayed at the IMG/ER 
Table 4. Number of genes associated with the 25 general COG functional categories

\begin{tabular}{|c|c|c|c|}
\hline Code & Value & \%age & Description \\
\hline$J$ & 208 & 4.60 & Translation \\
\hline A & 1 & 0.02 & RNA processing and modification \\
\hline K & 352 & 7.78 & Transcription \\
\hline $\mathrm{L}$ & 162 & 3.58 & Replication, recombination and repair \\
\hline B & 1 & 0.02 & Chromatin structure and dynamics \\
\hline $\mathrm{D}$ & 42 & 0.93 & Cell cycle control, mitosis and meiosis \\
\hline Y & - & - & Nuclear structure \\
\hline V & 48 & 1.06 & Defense mechanisms \\
\hline $\mathrm{T}$ & 332 & 7.34 & Signal transduction mechanisms \\
\hline M & 275 & 6.08 & Cell wall/membrane biogenesis \\
\hline N & 159 & 3.52 & Cell motility \\
\hline Z & 1 & 0.02 & Cytoskeleton \\
\hline W & - & - & Extracellular structures \\
\hline$U$ & 140 & 3.10 & Intracellular trafficking and secretion \\
\hline $\mathrm{O}$ & 156 & 3.45 & Posttranslational modification, protein turnover, chaperones \\
\hline $\mathrm{C}$ & 230 & 5.09 & Energy production and conversion \\
\hline G & 265 & 5.86 & Carbohydrate transport and metabolism \\
\hline $\mathrm{E}$ & 439 & 9.71 & Amino acid transport and metabolism \\
\hline $\mathrm{F}$ & 90 & 1.99 & Nucleotide transport and metabolism \\
\hline $\mathrm{H}$ & 177 & 3.91 & Coenzyme transport and metabolism \\
\hline I & 152 & 3.36 & Lipid transport and metabolism \\
\hline$P$ & 268 & 5.93 & Inorganic ion transport and metabolism \\
\hline Q & 122 & 2.70 & Secondary metabolites biosynthesis, transport and catabolism \\
\hline $\mathrm{R}$ & 515 & 11.39 & General function prediction only \\
\hline S & 388 & 8.58 & Function unknown \\
\hline - & 1,008 & 20.08 & Not in COGs \\
\hline
\end{tabular}




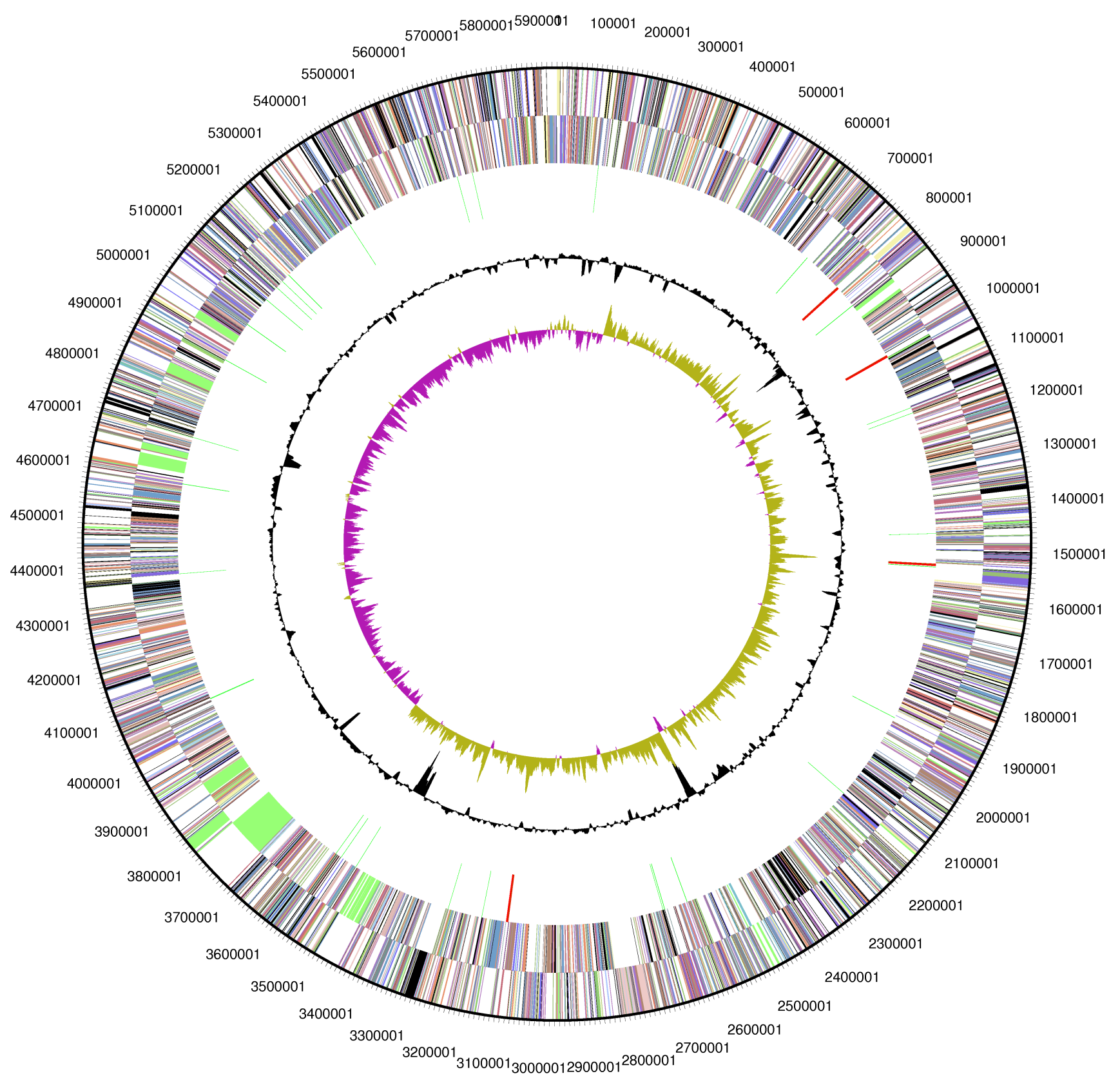

Figure 2. Graphical map of the chromosome. From outside to the center: genes on forward strand (colored by COG categories), genes on reverse strand (colored by COG categories), RNA genes: tRNAs - green, rRNAs - red, other RNAs - black, GC content, and GC skew

\section{Acknowledgements}

The authors would like to thank Dr. Daria Zhurina for her useful suggestions on the gap closure and the annotation procedures. This project was supported by the
Swiss National Science Foundation (31003A-134936) and the Foundation for Research in Science and the Humanities at the University of Zurich.

\section{References}

1. Bradbury JF. Guide to Plant Pathogenic. Kew, England: CAB International Mycological Institute; 1985:175-177.

2. González AJ, Landeras E, Mendoza MC. Pathovars of causing bacterial brown spot and halo blight in Phaseolus vulgaris L. are distinguisha- 
ble by ribotyping. Appl Environ Microbiol 2000; 66:850-854

3. Qi M, Wang D, Bradley CA, Zhao Y. Genome sequence analyses of pv. glycinea and subtractive hybridization-based comparative genomics with nine pseudomonads. PLOS ONE 2011; 6:e16451.

4. Young JM. Taxonomy of. Journal of Plant Pathology 2010;92:S1.5-S1.14. Available at:

http://sipav.org/main/jpp/index.php/jpp/article/vie w/2501. Accessed March 20, 2013.

5. Palleroni N. Genus I.. In: Garrity G, Brenner D, Krieg N, Staley J, eds. Bergey's Manual of Systematic Bacteriology, Second Edition, Volume 2, Part B. Springer; 2005:374.

6. Lindeberg $M$, Cunnac $S$, Collmer A. The evolution of host specificity and type III effector repertoires. Mol Plant Pathol 2009; 10:767-775.

7. Haapalainen $M$, Mosorin $H$, Dorati F, Wu RF, Roine E, Taira S, Nissinen R, Mattinen L, Jackson R, Pirhonen M, Lin NC. Hcp2, a secreted protein of the phytopathogen pv. tomato DC3000, is required for fitness for competition against bacteria and yeasts. J Bacteriol 2012; 194:4810-4822.

8. Lindeberg M, Cunnac S, Collmer A. type III effector repertoires: last words in endless arguments.

Trends Microbiol 2012; 20:199-208;. PubMed http://dx.doi.org/10.1016/j.tim.2012.01.003

9. Schellenberg B, Ramel C, Dudler R. Virulence Factor Syringolin A Counteracts Stomatal Immunity by Proteasome Inhibition. Mol Plant Microbe Interact 2010; 23:1287-1293;. PubMed http://dx.doi.org/10.1094/MPMI-04-10-0094

10. Bender CL, Alarcón-Chaidez F, Gross DC. phytotoxins: mode of action, regulation, and biosynthesis by peptide and polyketide synthetases. Microbiology and molecular biology reviews. Microbiol Mol Biol Rev 1999; 63:266-292;. PubMed

11. Denny TP. Involvement of bacterial polysaccharides in plant pathogenesis. Annu Rev Phytopathol 1995; 33:173-197. PubMed http://dx.doi.org/10.1146/annurev.py.33.090195. $\underline{001133}$

12. Feil $H$, Feil WS, Chain $P$, Larimer F, DiBartolo $G$, Copeland A, Lykidis A, Trong S, Nolan M, Goltsman E, et al. Comparison of the complete genome sequences of pv. syringae B728a and pv. tomato DC3000. Proc Natl Acad Sci USA 2005; 102:11064-11069.

13. Buell CR, Joardar $V$, Lindeberg $M$, Selengut J, Paulsen IT, Gwinn ML, Dodson RJ, Deboy RT,
Durkin AS, Kolonay JF, et al. The complete genome sequence of the Arabidopsis and tomato pathogen pv. tomato DC3000. Proc Natl Acad Sci USA 2003; 100:10181-10186.

14. Joardar $\mathrm{V}$, Lindeberg $M$, Jackson RW, Selengut J, Dodson R, Brinkac LM, Daugherty SC, Deboy R, Durkin AS, Giglio MG, et al. Whole-genome sequence analysis of pv. phaseolicola 1448A reveals divergence among pathovars in genes involved in virulence and transposition. J Bacteriol 2005; 187:6488-6498.

15. Denny TP. Phenotypic Diversity in pv. tomato. Microbiology 1988; 134:1939-1948.

16. Hwang MSH, Morgan RL, Sarkar SF, Wang PW, Guttman DS. Phylogenetic characterization of virulence and resistance phenotypes of. Appl Environ Microbiol 2005; 71:5182-5191.

17. Sundin GW, Demezas DH, Bender CL. Genetic and plasmid diversity within natural populations of with various exposures to copper and streptomycin bactericides. Appl Environ Microbiol 1994; 60:4421-4431.

18. Denny TP, Gilmour MN, Selander RK. Genetic Diversity and Relationships of Two Pathovars of. J Gen Microbiol 1988; 134:1949-1960.

19. Young JM, Dye DW, Bradbury JF, Panagopoulos CG, Robbs CF. A proposed nomenclature and classification for plant pathogenic bacteria. N Z J Agric Res 1978; 21:153-177. http://dx.doi.org/10.1080/00288233.1978.10427 $\underline{397}$

20. Gardan L, Shafik H, Belouin S, Broch R, Grimont $F$, Grimont PAD. DNA relatedness among the pathovars of and description of sp. nov. and sp. nov. (ex Sutic and Dowson 1959). Int J Syst Bacteriol 1999; 49:469-478.

21. Gardan L, Bollet C, Abu Ghorrah M, Grimont F, Grimont PAD. DNA Relatedness among the Pathovar Strains ofastanoi Janse (1982) and Proposal of sp. nov. Int / Syst Bacteriol 1992; 42:606612.

22. Baltrus DA, Nishimura MT, Romanchuk A, Chang JH, Mukhtar MS, Cherkis K, Roach J, Grant SR, Jones CD, Dangl JL. Dynamic evolution of pathogenicity revealed by sequencing and comparative genomics of 19 isolates. PLoS Pathog 2011; 7:e1002132.

23. Field D, Garrity G, Gray T, Morrison N, Selengut J, Sterk P, Tatusova T, Thomson N, Allen MJ, Angiuoli SV, et al. The minimum information about a genome sequence (MIGS) specification. 
Nat Biotechnol 2008; 26:541-547. PubMed

http://dx.doi.org/10.1038/nbt1360

24. Woese CR. Towards a Natural System of Organisms: Proposal for the Domains, , and Eucarya. Proc Natl Acad Sci USA 1990; 87:4576-4579.

25. Garrity GM, Bell JA, Lilburn T. Phylum XIV. phyl. nov. In: Garrity GM, Brenner DJ, Krieg NR, Staley JT (eds), Bergey's Manual of Systematic Bacteriology, Second Edition, Volume 2, Part B, Springer, New York, 2005, p. 1.

26. Validation of publication of new names and new combinations previously effectively published outside the IJSEM. List no. 106. Int J Syst Evol Microbiol 2005; 55:2235-2238. http://dx.doi.org/10.1099/ijs.0.64108-0

27. Garrity GM, Bell JA, Lilburn T. Class III. class. nov. In: Garrity GM, Brenner DJ, Krieg NR, Staley JT (eds), Bergey's Manual of Systematic Bacteriology, Second Edition, Volume 2, Part B, Springer, New York, 2005, p. 1.

28. Skerman VBD, McGowan V, Sneath PHA. Approved Lists of Bacterial Names. Int J Syst

Bacteriol 1980; 30:225-420.

http://dx.doi.org/10.1099/00207713-30-1-225

29. Orla-Jensen S. The main lines of the natural bacterial system. / Bacteriol 1921; 6:263-273. PubMed

30. Garrity G, Bell J, Lilburn T. Order IX. Pseudomonales. In: Garrity G, Brenner D, Krieg N, Staley J, eds. Bergey's Manual of Systematic Bacteriology, Second Edition, Volume 2, Part B. Springer, New York; 2005:323.

31. Winslow CEA, Broadhurst J, Buchanan RE, Krumwiede C, Rogers LA, Smith GH. The Families and Genera of the: Preliminary Report of the Committee of the Society of American Bacteriologists on Characterization and Classification of Bacterial Types. J Bacteriol 1917; 2:505-566.

32. Migula W. Über ein neues System der Bakterien. Arb. Bakteriol. Inst. Karlsruhe 1894; 1:235-238.

33. Doudoroff M, Palleroni NJ. Genus Migula 1894, 237; Nom. cons. Opin. 5, Jud. Comm. 1952, 121. In: Buchanan RE, Gibbons NE (eds), Bergey's Manual of Determinative Bacteriology, Eighth Edition, The Williams and Wilkins Co., Baltimore, 1974 , p. 217-243.

34. Judicial Commission. Opinion 5: Conservation of the Generic Name Migula 1894 and Designation of Aeruginosa (Schroeter) Migula 1900 as Type Species. Int Bull Bacteriol Nomencl Taxon 1952; 2:121-122.
35. van Hall CJJPD. Dissertation, University of Amsterdam, 1902, p. 198.

36. Palleroni N. Genus I.. In: Garrity G, Brenner D, Krieg N, Staley J, eds. Bergey's Manual of Systematic Bacteriology, Second Edition, Volume 2, Part B. Springer, New York; 2005:373-377.

37. Palleroni N. Genus I.. In: Garrity G, Brenner D, Krieg N, Staley J, eds. Bergey's Manual of Systematic Bacteriology, Second Edition, Volume 2, Part B. Springer, New York; 2005:323-357.

38. Young JM, Luketina RC, Marshall AM. The Effects on Temperature on Growth in vitro of and pruni. I Appl Bacteriol 1977; 42:345-354.

39. Ashburner M, Ball CA, Blake JA, Botstein D, Butler $\mathrm{H}$, Cherry JM, Davis AP, Dolinski K, Dwight SS, Eppig JT, et al. Gene Ontology: tool for the unification of biology. Nat Genet 2000; 25:25-29. $\underline{\text { PubMed http://dx.doi.org/10.1038/75556 }}$

40. Sarkar SF, Guttman DS. Evolution of the Core Genome of, a Highly Clonal, Endemic Plant Pathogen. Appl Environ Microbiol 2004; 70:19992012.

41. Tamura K, Peterson D, Peterson N, Stecher G, Nei M, Kumar S. MEGA5: molecular evolutionary genetics analysis using maximum likelihood, evolutionary distance, and maximum parsimony methods. Mol Biol Evol 2011; 28:2731-2739. PubMed http://dx.doi.org/10.1093/molbev/msr121

42. Bertani G. Studies on lysogenesis. I. The mode of phage liberation by lysogenic. I Bacteriol 1951; 62:293-300.

43. King EO, Ward M, Raney D. Two simple media for the demonstration of pyocyanin and fluorescin. J Lab Clin Med 1954; 44:301-307. PubMed

44. Palmer DA, Bender CL. Effects of Environmental and Nutritional Factors on Production of the Polyketide Phytotoxin Coronatine by pv. Glycinea. Appl Environ Microbiol 1993; 59:16191626.

45. Feil H, Feil WS, Chain P, Larimer F, DiBartolo G, Copeland A, Lykidis A, Trong S, Nolan M, Goltsman E. Crown Gall of Stone Fruit II. Identification and Nomenclature of Isolates. Aust J Biol Sci 1970; 23:585-596.

46. Gasson MJ. Indicator Technique for Antimetabolic Toxin Production by Phytopathogenic Species of. Appl Environ Microbiol 1980; 39:25-29. 
47. Clark DJ, Maaløe O. DNA replication and the division cycle in. J Mol Biol 1967; 23:99-112.

48. Mo YY, Gross DC. Plant signal molecules activate the syrB gene, which is required for syringomycin production by pv. syringae. I Bacteriol 1991; 173:5784-5792.

49. Amrein H, Makart S, Granado J, Shakya R, Schneider-Pokorny J, Dudler R. Functional analysis of genes involved in the synthesis of syringolin A by pv. syringae B301 D-R. Molecular plantmicrobe interactions. Mol Plant Microbe Interact 2004; 17:90-97.

50. Aziz RK, Bartels D, Best AA, Dejongh M, Disz T, Edwards RA, Formsma K, Gerdes S, Glass EM, Kubal M, et al. The RAST Server: rapid annotations using subsystems technology. BMC Genomics 2008; 9:75. PubMed http://dx.doi.org/10.1186/1471-2164-9-75

51. Seemann T. Prokka: Prokaryotic Genome Annotation System. 2012. Available at: http://vicbioinformatics.com/.

52. Hyatt $\mathrm{D}$, Chen GL, Locascio PF, Land ML, Larimer FW, Hauser LJ. Prodigal: prokaryotic gene recognition and translation initiation site identification. BMC Bioinformatics 2010; 11:119. PubMed http://dx.doi.org/10.1186/1471-2105-11-119

53. Delcher AL, Bratke KA, Powers EC, Salzberg SL. Identifying bacterial genes and endosymbiont DNA with Glimmer. Bioinformatics 2007; 23:673-679. PubMed http://dx.doi.org/10.1093/bioinformatics/btm009

54. Altschul SF, Gish W, Miller W, Myers EW, Lipman DJ. Basic local alignment search tool. J Mol Biol 1990; 215:403-410. PubMed

55. Marchler-Bauer A, Lu S, Anderson JB, Chitsaz F, Derbyshire MK, DeWeese-Scott C, Fong JH, Geer LY, Geer RC, Gonzales NR, et al. CDD: a Con- served Domain Database for the functional annotation of proteins. Nucleic Acids Res 2011; 39:D225-D229. PubMed http://dx.doi.org/10.1093/nar/gkq1189

56. Markowitz VM, Mavromatis K, Ivanova NN, Chen IMA, Chu K, Kyrpides NC. IMG ER: a system for microbial genome annotation expert review and curation. Bioinformatics 2009; 25:2271-2278. PubMed http://dx.doi.org/10.1093/bioinformatics/btp393

57. Groll M, Schellenberg B, Bachmann AS, Archer CR, Huber R, Powell TK, Lindow S, Kaiser M, Dudler R. A plant pathogen virulence factor inhibits the eukaryotic proteasome by a novel mechanism. Nature 2008; 452:755-758. PubMed http://dx.doi.org/10.1038/nature06782

58. Cunnac S, Chakravarthy S, Kvitko BH, Russell AB, Martin GB, Collmer A. Genetic disassembly and combinatorial reassembly identify a minimal functional repertoire of type III effectors in. Proc Natl Acad Sci USA 2011; 108:2975-2980.

59. Arrebola E, Cazorla FM, Codina JC, GutiérrezBarranquero JA, Pérez-García A, De Vicente A. Contribution of mangotoxin to the virulence and epiphytic fitness of pv. syringae. International microbiology: the official journal of the Spanish Society for Microbiology 2009;12:87-95.

60. Poole K. Multidrug efflux pumps and antimicrobial resistance in and related organisms. / Mol Microbiol Biotechnol 2001; 3:255-264.

61. Mima T, Sekiya H, Mizushima T, Kuroda T, Tsuchiya T. Gene cloning and properties of the RND-type multidrug efflux pumps MexPQ-OpmE and MexMN-OprM from. Microbiol Immunol 2005; 49:999-1002. 